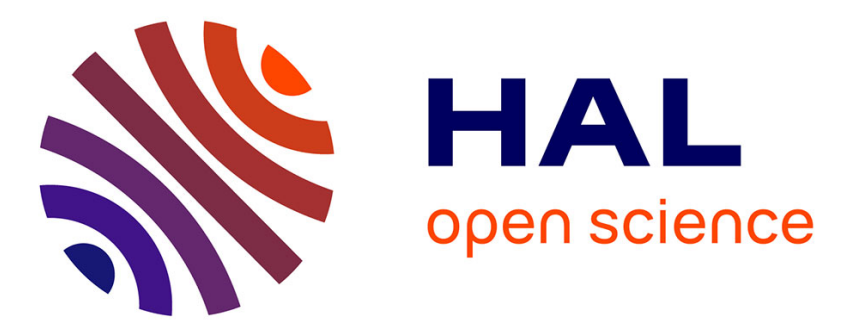

\title{
Oligochaete assemblages in the hyporheic zone and coarse surface sediments: their importance for understanding of ecological functioning of watercourses
}

\author{
M. Lafont, A. Vivier
}

\section{- To cite this version:}

M. Lafont, A. Vivier. Oligochaete assemblages in the hyporheic zone and coarse surface sediments: their importance for understanding of ecological functioning of watercourses. Hydrobiologia, 2006, 564, p. 171 - p. $181.10 .1007 /$ s10750-005-1717-9 . hal-00452234

\author{
HAL Id: hal-00452234 \\ https://hal.science/hal-00452234
}

Submitted on 1 Feb 2010

HAL is a multi-disciplinary open access archive for the deposit and dissemination of scientific research documents, whether they are published or not. The documents may come from teaching and research institutions in France or abroad, or from public or private research centers.
L'archive ouverte pluridisciplinaire HAL, est destinée au dépôt et à la diffusion de documents scientifiques de niveau recherche, publiés ou non, émanant des établissements d'enseignement et de recherche français ou étrangers, des laboratoires publics ou privés. 
Lafont, M. and Vivier, A. (2006). Oligochaete assemblages in the hyporheic zone and coarse surface sediments: their importance for understanding of ecological functioning of watercourses. Hydrobiologia. 564: 171-181.

Published version available online at http://www.springerlink.com/ DOI: 10.1007/s10750-005-1717-9

This material is presented to ensure timely dissemination of scholarly and technical work. Copyright and all rights therein are retained by authors or by other copyright holders. All persons copying this information are expected to adhere to the terms and constraints invoked by each author's copyright. In most cases, these works may not be reposted without the explicit permission of the copyright holder.

Nous mettons ce document à disposition sous cette forme dans le but d'assurer la plus grande diffusion de nos travaux scientifiques et techniques, en particulier auprès des étudiants. Le copyright et tous les droits restent la propriété des auteurs et des éditeurs. Nous prions chaque personne utilisant ces informations de respecter les droits et copyright des auteurs et éditeurs. Dans la plupart des cas, ces travaux ne peuvent être réexpédiés sans la permission explicite du détenteur des droits. 
Oligochaete assemblages in the hyporheic zone and coarse surface sediments: their importance for understanding of ecological functioning of watercourses.

Michel Lafont* and Anne Vivier**

* Cemagref, Biology Research Unit, 3 bis Quai Chauveau, C.P. 220, F-69336 Lyon Cedex 09 (France) ; lafont@lyon.cemagref.fr

** ENGEES, SHU Laboratory, 3 bis Quai Koch, 67000 Strasbourg (France)

Keywords: Running waters, coarse sediments, hyporheic zone, Oligochaeta

This paper has not been submitted elsewhere in identical or similar form, nor will it be during the first three months after its submission to Hydrobiologia. 
Abstract.

The hyporheic zone and its interactions with coarse surface sediments is increasingly reported by aquatic ecologists because the water exchanges between surface and subsurface are important factors for the understanding of the ecosystem functioning. However, the hyproheic oligochaete assemblages have received less attention than other assemblages such as crustaceans. In addition, studies investigating the incidence of pollution in watercourses have mostly focused on the benthic zone and have neglected the hyporheic zone. Some examples are given from an unpolluted glacial river (Roseg), polluted plains rivers (Moselle, Rhône) and a protected wetland in an urbanized environment. The hyporheic zone kept the memory of past and present incidences of pollution, in particular when downwellings of polluted surface waters to the hyporheic zone predominated. The Active hydrologic Exchange Describers between surface and subsurface (AED oligochaete species) were the same in the glacial river Roseg, the rivers Rhône and Moselle and the urbanized wetland. The predominance of pollution-tolerant species like Limnodrilus hoffmeisteri was observed in polluted groundwater as well as in polluted surface coarse sediments. Moreover, the urbanized wetland exhibited a high species richness, suggesting that the hyporheic zone is a reservoir of species. The oligochaete communities enable biologists to simultaneously assess the pollution incidence, the permeability of coarse habitats, the water exchanges between surface and subsurface, and give an approximate measure of the metabolic activities in the sediments. Consequently, the simultaneous study of surface and hyporheic oligochaete assemblages is of great interest when considering the ecological functioning of watercourses and the incidence of pollution inputs. 


\section{Introduction}

This paper does not represent an exhaustive survey of research contributions and as such is very incomplete regarding the study of surface coarse and hyporheic sediments for the watercourse functioning evaluation. We tried to underline what should be reasonably attainable when dealing with the ecology of oligochaete assemblages living in coarse surface sediments and the hyproheic zone, and their importance for understanding of ecological functioning of watercourses.

The hyporheic zone may be defined as the saturated interstitial areas beneath the stream bed and into the stream banks that contain some proportion of channel water (Gibert et al., 1990; Vervier et al., 1992; White, 1993). Underestimated for a long time, its relations with surface waters and its importance for understanding the ecology of river corridors is now well recognized (Hynes, 1983; Bencala, 1993; Boulton, 2000; Bretschko, 1991; Brunke \& Gonser, 1997; Danielopol, 1984, 1989; Gibert et al., 1990; Hancock, 2002; Jones \& Mulholland, 2000; Malard et al., 2002, 2003; Triska et al., 1990; Valett et al., 1993). Ward (1989) pointed out the four dimensional (length, width, depth, time) structure of lotic ecosystems. Fellows et al. (2001) demonstrated that 40 to $93 \%$ of the whole stream respiration occurred in the hyporheic zone. These authors also demonstrated that important ecological processes can occur in the shallow but hydrologically dynamic hyporheic zone.

The bottom of watercourses formed in coarse-grained sediments is related to the hyporheic system and is the prime habitat where water exchanges between surface and subsurface occur. Coarse sediments generally predominate in the majority of freshwater ecosystems in France, excluding the deep zones of lakes, reservoirs, some back waters and aquatic habitats in the wetlands, but including the littoral zone of many lakes, including Lake Geneva. For example, the deep zones of the river Rhône are composed of coarse sand and gravel at $8 \mathrm{~m}$ depth downstream of the urban area of Lyon, although the width of the river is about $200 \mathrm{~m}$ (Lafont et al., 1992). Even in the slow-flowing river Saône, at Site Auxonne (150 metres width, current velocity less than $0.1 \mathrm{~m} . \mathrm{s}^{-1}$.), the fine-grained sediments are restricted to the bank areas where coarse sediments also predominate. The deep zone (-4 metres) is composed of gravel and coarse sand (Lafont, 1989 and unpublished data). 
The benthic habitats of running waters formed by coarse sediment and the hyporheic habitats display a high permeability. The efficiency of permeable sediments in the degradation of organic matter was for a long time recognized (Bou, 1977; Solbe, 1975; Solbe et al., 1974; Williams \& Taylor, 1968 ) and used for purification processes in waste-water treatment plants (Bruce et al., 1983, cited by Datry et al., 2003). Their study in natural watercourses presents a challenging task for present and future researches. Research is now focusing on this domain and numerous recent papers have underlined the strong physicochemical and biological connections between surface and groundwater, and their importance for the ecological study of lotic ecosystems (Boulton, 2000; Boulton et al., 2003; Hancock, 2002). To date biological studies were mostly devoted to metabolic and microbial activities (see Jones \& Mulholland, 2000; Griebler et al., 2001), or to crustacean assemblages (see Griebler et al., 2001). The oligochaete assemblages received much less attention and research on that subject progressed more slowly than the biogeochemical and hyodrological studies (Stanley \& Jones, 2000), with generally a disconnection between the consideration of surface and subsurface zones (Boulton, 2000).

\section{Interstitial oligochaete assemblages and watercourse functioning}

\section{Overview}

Oligochaete assemblages are well-known as common inhabitants of surface sediments and hyporheic zone, and they are also significant colonizers of groundwater, especially in deep karstic zones (Malard, 2001). The consideration of a batch of 93 species demonstrated that at least 62 species were collected both in surface and groundwater (Lafont, 1989). Moreover, the oligochaete assemblages may occur at all depths, from the surface to the deep hyporheos (Weigelhofer \& Waringer, 2003). In addition, it is less mentioned that the surface coarse sediments shelter the richest assemblages of oligochaetes (Lafont, 1989). Oligochaetes firmly keep their historical status of "sludge worms", giving the impression that they are only an accessory fauna in coarse sediments, whilst the Arthropods are the main faunal elements. Moreover, the use of unsuitable filtration methods, for example $0.500 \mathrm{~mm}$ mesh-size which is commonly used in macrobenthos studies, leads to a significant 
underestimation of oligochaete densities (Nalepa \& Robertson, 1981) and the loss of about $50 \%$ of the species (Lafont, 1989). The species richness of small oligochaetes is greater, and this is particularly true in the interstices of the surface coarse sediments and hyporheic system, which generally shelter the smallest species. For example, in the Family Tubificidae, Branchiura sowerbyi, Tubifex tubifex or Limnodrilus spp. are giant species compared to members of the Rhyacodrilinae. Even Nais elinguis may be a giant compared to Rhyacodrilus falciformis, small Phallodrilinae, or species of the genus Cernosvitoviella.

The hyporheic oligochaetes have been less studied than other assemblages (e.g. crustaceans), with the exception of pioneer contributions like those of Botea (1963), Ladle (1971), Ferrarese \& Sambugar (1976), Bird (1982), Schwank (1982a, 1982b), Dole (1983), Gaschignard (1984), Dumnicka (1986), Juget (1980, 1984, 1987), Juget \& Dumnicka (1986), Strayer \& Bannon O’Donnell (1988).

The lack of studies involving both invertebrate communities and hydrologic measurements has been pointed out (Boulton, 2000), but this is not surprising because multidisciplinary researches are generally more difficult to organize. However, multidisciplinary studies put to the light more interesting findings than the sole consideration of biology or hydrology (Lafont et al., 1992; Valett et al., 1993).

\section{Examples from case studies}

\section{River Rhône at Grand Gravier site: definition of AED species}

A first example is given by the comparison between oligochaete species and hydrologic measurements at a suburban polluted site (the "Grand Gravier") of the River Rhône downstream of the suburban area of Lyon (Lafont \& Durbec, 1990). The hydrodynamic parameters were measured at a site about 500 metres long. Within this site, two stations of 50 metres each were selected and the filtration velocity of water through the sediments was assessed by piezometric measurements ( 2 transects per station). Station 1 (transects T1 and T2, Table 1) was characterized by a significant lower filtration velocity than Station 2 (T3 and T4). At both stations, oligochaeta were sampled in surface coarse sediments by means of a Surber net and a metallic corer driven into the substrate by a hammer (depth of the samples: 0 to $100 \mathrm{~mm}$ ). A mesh-size of $0.160 \mathrm{~mm}$ was retained for the sediment 
filtration. The identification of oligochaetes was conducted to the level of species and informed us about several exciting features:

1) although a polluted site, the species richness was relatively high (33 species);

2) the biological quality of Station 2 (greater filtration velocity) was significantly better than that of Station 1, and this was related to a decrease of the percentages of pollution-tolerant Tubificidae;

3) at Station 2, a significant increase in the percentages of Gianius riparius (Phallodrilus riparius), Stylodrilus spp., Pristina and Pristinella spp., Marionina argentea, Spirosperma velutinus and Cernosvitoviella atrata was observed. These species were already known as groundwater dwellers and their significant abundances in surface sediments related to upwellings of groundwater (Botea, 1962; Gashignard, 1984; Juget, 1980, 1984, 1987; Juget \& Dumnicka, 1986; Lafont, 1989).

A second field investigation was performed in the same site at three different depths $(-1.5,-4$ and -8 metres, Table 1). Biological samples ware taken using the same Surber type net operated by divers and the mean filtration velocities were available at these stations (Lafont et al., 1992). A significant increase in percentages of groundwater dwellers (Stylodrilus spp., S. velutinus, Rhyacodrilus sp., Pristinella osborni) was observed at $4 \mathrm{~m}$ depth, where the filtration velocities through the sediments were greater (mean filtration velocity: $6.3 \mathrm{~m} \mathrm{day}^{-1}$ ). Conversely, the pollutiontolerant species did not significantly decline. More surprising was the increase of the percentages of Psammoryctides barbatus at $-4 \mathrm{~m}$, probably in relation to the predominance of coarse sand (Lafont et al., 1992). The results were more complex than expected, but suggested that the relations between filtration velocities and the percentages of groundwater-dwelling oligochaetes followed a linear pattern.

After these two field studies, the groundwater-dwelling oligochaetes were considered as Active Exchange Describers between surface and subsurface (AED species, Lafont et al., 1992), because 1) they were primarily groundwater dwellers and;2) they predominated in the surface layers where filtration velocities through hyporheic sediments were greater. A list of Active Exchange Describers (AED) was proposed (Lafont et al., 1992) and is constantly improved (Table 2). 


\section{River Roseg}

In the glacial river Roseg (Switzerland), the upwellings of groundwater were measured by chemical analyses of the $\mathrm{SiO}_{2}$ contents. Malard et al. (1999) showed that silica was an effective tracer of groundwater input to the river. Benthic oligochaetes were sampled with a Hess-sampler (sampling area: $0.043 \mathrm{~m}^{2}$ ). Hyporheic oligochaetes were collected by driving a mobile pipe to a depth of $30 \mathrm{~cm}$ below the streambed (Malard et al., 2001). Ten litres of interstitial water were extracted using a BouRouch pump (Bou \& Rouch, 1967). The benthic and hyporheic samples were filtered through a 0.100 $\mathrm{mm}$ mesh size. The hyporheic oligochaete assemblages exhibited significant species richness and abundances only at stations where upwellings of groundwater occurred (Lafont \& Malard, 2001). Nearly all the collected species belonged to AED indicator taxa (Table 2), with the exception of Nais communis, a superficial species suspected to have developed morphological and physiological adaptations to subterranean life (Lafont \& Malard, 2001). The benthic oligochaetes followed quite similar distribution patterns at stations where significant upwellings of groundwater occurred (Malard et al., 2001). The same predominant species were collected both in the surface and hyproheic sediments. The main difference was that the composition, abundance and distribution of oligochaete communities were more stable over time in the hyporheic system than in the benthic system.

\section{River Moselle}

In the river Moselle (France), the situation of surface water downwelling areas was also investigated, and we started from the hypothesis that they might be indicated by the invasion of subsurface areas by surface-dwelling oligochaete species. The oligochaete communities were collected at 5 stations both in surface and hyporheic sediments in June, August and October 1992 (Lafont et al., 1996). Benthic oligochaetes were sampled with a Surber net sampler (sampling area: $0.04 \mathrm{~m}^{2}$ ). Hyporheic oligochaetes were collected by driving a mobile pipe to a depth of $30 \mathrm{~cm}$ below the streambed, and ten litres of interstitial water were extracted using a Bou-Rouch pump (Bou and Rouch, 1967). The benthic and hyporheic samples were filtered through a $0.160 \mathrm{~mm}$ mesh size. The hydrologic measurements were restricted to the annual hydrographs of the river (1992). The use of a Factorial Correspondence Analysis (FCA) on the relative abundances of oligochaete species, collected 
in benthic and hyporheic samples, allowed to identify the three species groups which explained the first plane of the FCA (F1-F2 $=37 \%$ of the total inertia). Group 1 included two superficial Naididae species, Nais barbata and Nais bretscheri. Group 2 was characterized by the predominance of superficial Tubificidae taxa, which are well-known for their pollution-tolerance (Limnodrilus hoffmeisteri and immature worms without hair setae). Group 3 comprised the Active Exchange Describers (AED) (P. volki, Pristina longiseta, P. aequiseta foreli and P. jenkinae). The seasonal evolution of oligochaete assemblages at Station 1 (the less polluted situation, no water pumping) showed that, both in surface sediments and the hyporheic system, the assemblages changed from being a superficial Naididae population (Group 1) in June, to a population of AED species (Group 3) in August and October (Fig. 1). At Station 4, the most polluted situation (paper-mill industry) with intensive groundwater pumping, surface sediments and the hyporheic system were predominantly colonized by taxa of Group 2 (pollution-tolerant genus Limnodrilus, Fig.2). The dynamics of hydrological functioning, illustrated by the hydrographs, were consistent with the distribution of oligochaete assemblages at Station 1. The hyporheic system was invaded by surface species at the end of high surface water discharges (June, previous predominance of surface water downwellings). On the contrary, both surface sediments and the hyporheic system were invaded by AED species when low riverbed discharges occurred (August to October), suggesting that the river was predominantly fed by upwellings of groundwater. At Station 4, the predominance of the superficial and pollution-tolerant genus Limnodrilus, both in superficial sediments and the hyporheic system, was considered as the consequence of intensive pumping, the groundwater table being constantly low and downwellings of polluted surface water constantly predominating either during high or low riverbed discharges.

\section{River Rhône at Chasse-sur-Rhône site}

At Chasse-sur-Rhône, a polluted site of the river Rhône (downstream of the urban area of Lyon), the goal was to assess the vulnerability of a water-pumping area for drinking water supply (Durbec et al., 1992). The oligochaete samples were collected both in surface and hyporheic sediments in October 1992, under low river discharge conditions. The sampling methodology was strictly similar to the one used for studying the river Moselle. The 5 studied stations in the river were facing five 
pumping wells (P1 to P5) located into the banks. The percentages of pollution-tolerant species of Tubificidae were higher in the hyporheic zone than in the surface sediments at Stations P1 and P4, equal at P2 and P3 and lesser at P5 (Fig. 3). The biological features suggested: a) the predominance of downwellings of surface water at the whole site and the vulnerability of the groundwater resource to surface pollution, with Station P3 being the most vulnerable, and; b) the storage of pollution in the hyporheic system of P1 and P4, due to former downwellings. One sampling season was considered, however the biological results were in accordance with those of the hydrological study (Durbec et al., 1992), except for P2, where the hydrological study did not mention the vulnerability to pollution.

\section{Case of an urbanized site (Rhône basin)}

At the Crépieux-Charmy site (urban area of Lyon), an alluvial zone of about 375 hectares was delineated for the protection of the groundwater resource devoted to drinking water supply. The oligochaete and crustacean assemblages were sampled on three occasions (June and November 1993, July 1994) in the coarse surface and hyporheic sediments at 12 stations of the river Rhône, the Miribel and the Jonage canals. The sampling methodology was the same as the one used for studying the river Moselle and Chasse-sur-Rhône site. The surface waters were only slightly polluted as the area is upstream of the industrial activities (Camus \& Lafont, 1994). The oligochaete species richness accounted for at least 59 species, with rare species like Trichodrilus intermedius. When considering the 13 species only found at the Grand Gravier (Lafont \& Durbec, 1990; Lafont et al., 1992) and three others only found at Chasse-sur-Rhône (Durbec et al., 1992), the coarse and hyporheic sediments of these three urbanized sites (Crépieux-Charmy, Gand-Gravier, Chasse-sur-Rhône) sheltered at least 75 species. The examination of the percentages of superficial species in the hyporheic layer and of the AED species in the surface sediments enabled a map to be drawn of the hydrologic exchange zones

(Fig. 4). These results were in accordance with the global view of hydrologic evaluation, with the predominance of upwelling processes during low surface water discharges (July 1994, Fig. 4). The Crépieux-Charmy site gives an illustration of how to exploit oligochaete assemblages in integrated functional studies, although further refinements are expected (e.g. comparison of invertebrate 
assemblage patterns with hydrological modelling). This study also demonstrated the importance of surface coarse and hyporheic sediments for the protection of oligochaete biodiversity.

\section{Discussion, conclusion}

Very similar distribution patterns of surface and hyporheic oligochaete assemblages were obtained from different watercourses - the Moselle, the Rhône and the glacial river Roseg. Nine of the 16 oligochaete taxa collected from the river Roseg (Malard et al., 2001) were found in the CrépieuxCharmy and Grand Gravier areas. The 6 Active Exchange Describers (AED) of the river Roseg were all collected in the river Rhône (Table 2). The main difference is that the number of AED species is greater in the Rhône than in the Roseg, in relation to a less harsh environment.

The pollution-tolerant species found in the hyporheic zone of the river Moselle are the same as those that dwell in polluted surface sediments (Lafont et al., 1996). The same applies to karstic areas (Malard, 2001). The great interest when considering oligochaete assemblages lies in their simultaneous values as water exchange and pollution indicators, which are related to their ability to colonize both surface and groundwater habitats. The studies of the river Moselle and river Rhône at the Chasse-surRhône site led us to the view that the hyporheic system keeps the "memory" of past and present pollutions in stony streams and rivers (Lafont et al., 1996). This concept was strengthened by results obtained from the study of the ecological incidence of intermittent pollutions (combined sewer overflows CSOs) at four stations of a suburban stream (stream Chaudanne, Lafont et al., accepted). The pollution indicators Tubifex tubifex and Lumbricillus rivalis predominated, from April 2000 to April 2001, in the hyporheic system at Station 4, located $500 \mathrm{~m}$ downstream of the CSOs, indicating that the hyporheic interstices became soaked with polluted sludge. This situation was related to high ammonium salt contents in the hyporheic waters and suggested that downwellings of polluted waters predominated. Moreover, T. tubifex and L. rivalis significantly occurred in the coarse surface sediments at Station 4 only when the CSOs were high and stream discharges very low (August to the beginning of October 2000). These results emphasized the general view that coarse surface sediments are more exposed to the variations of surface hydraulic conditions and more unstable than the 
hyporheic system (Giere, 1993), a situation also illustrated by the study of the river Roseg (Malard et al., 2001). In consequence, the benthic sediments give incomplete diagnoses of pollution effects.

The concept of the vulnerability of groundwater to a surface pollution was previously proposed (Lafont et al., 1992, 1996). However, this was a simplistic view as the hyporheic zone may also contaminate the surface sediments, a feature which is well-documented regarding nutrients (Holmes, 2000) -that probably exists in the rivers Moselle and Rhône. Moreover, the surface sediments are not always permanently saturated and can become exposed during low water discharges, or removed during floods. Conversely, the hyporheic system is generally permanently saturated, even when the surface stream-bed has dried up, and it remains intact during floods, particularly in the deeper layers (McElravy \& Resch, 1991). Because of this, the hyporheic zone may accumulate more pollutants. In conclusion, for fundamental or applied studies, the sole consideration of the surface sediments gives us incomplete information (Danielopol, 1989; Ferrarese \& Sambugar, 1976; Hynes, 1983; Rouch \& Danielopol, 1987; Ward \& Palmer, 1994). In the case of pollution studies, it is a serious gap which might lead to a biased view about the state of ecological degradation. Furthermore, as the self-purification capacities of a river are strongly related to the hydric exchanges between surface and subsurface (Hancock, 2002), the biological assessment of downwellings (predominance of superficial species in the hyporheic zone) and upwellings (predominance of AED species in the surface sediments) would be very useful in the functional studies of watercourses where coarse sediments predominate.

Unfortunately, most biomonitoring schemes focus on the surface habitats and neglect the hyporheic system. In France, the IBGN index (invertebrate index, Afnor, 1992), the diatom index IBD (Afnor, 2000) and the oligochaete index IOBS (Afnor, 2002) only refer to the surface habitats. The biomonitoring of hyporheic zones remains disconnected from that of the benthic system, except some valuable recent proposals (Boulton, 2000; Boulton et al., 2003). This situation is not satisfactory because of the close connections between surface and groundwater.

The value of oligochaetes as pollution indicators is well-recognized, as well as their strong relations with organic matter which is for example attested by their role in wastewater treatments (Bou, 1977; Bruce et al., 1983, cited by Datry et al., 2003). Oligochaete metabolic activity in coarse 
sediments and the hyporheic zone is well less known. This is an important ecological trait which has not been studied enough, but is in the course of being developed in field (Datry et al., 2003) and experimental case studies (Mermillot-Blandin et al., 2003).

The value of oligochaete assemblages as indicators of pollution, metabolic activities and water exchange is shared with other biocenoses. However the attractive characteristic of oligochaetes is that they might enable biologists to simultaneously assess the effects of pollution, dynamics of water exchanges and metabolic activities. Conversely, oligochaetes are not universal indicators and other taxocenoses must be considered to supplement and refine the diagnoses. The simultaneous use of crustacean and oligochaete communities at the Crépieux-Charmy site (Fig. 4) is a good example of an integrated ecological diagnosis. If the ecological value of oligochaetes in surface coarse sediments and the hyporheic system was until now underestimated, it is also important not to overestimate their importance.

The present and relevant classifications of groundwater organisms (stygoxene, stygophile and stygobite organisms) (Claret et al., 1999) were historically based on the examination of crustacean assemblages or aquatic insect larvae. However, oligochaete species do not easily fit into these classifications and new proposals must be made. The hyporheic zone is generally considered as an ecotone and a refuge during floods or drought (Gibert, 2001). Regarding oligochaete communities, the hyporheic zone might be above all a reservoir of species, and probably the main route for the dissemination of species (Lafont \& Malard, 2001). These observations are consistent with the concepts of Brestsko (1991) and Naiman et al. (1988, cited by Brestchko 1991).

As a conclusion, it is suggested that the study of coarse surface sediments and hyporheic systems is indispensable to understand the ecological functioning of watercourses. The fine sediments must be considered in biomonitoring studies (Lafont et al., 2001), but in watercourses where the coarse sediments predominate, the interest of fine sediments for the understanding of river functions declines when their percentage cover of the river bed is reduced (Lafont, 2001). Our present research focuses now on the study of surface coarse sediments and the hyporheic system, with special reference to the comparison between the distributions of invertebrate assemblages, the modelling of hydrological exchanges and the geomorphological background. 


\section{Acknowledgements}

We thank D. Danielopol for his kind proposal of commenting on our manuscript, also F. Malard for his help before the Nine International Symposium on Oligochaete Biology. We are gratefully indebted to the two anonymous reviewers for their comments that enabled us to significantly improve the manuscript. This work was partly funded by the European Project URBEM (Urban Water Enhancement Methods).

\section{References}

Afnor, 1992. Détermination de l'indice biologique global normalisé (IBGN). NF T 90-350.

Afnor, 2000. Détermination de l’Indice biologique Diatomées (IBD). NF T 90-354.

Afnor, 2002. Détermination de l'indice oligochètes de bioindication des sédiments (IOBS). NF T 90390.

Bencala, K. E., 1993. A perspective on stream-catchment connections. Journal of the North American Benthological Society 12: 44-47.

Bird, G.J., 1982. Distribution, life cycle and population dynamics of the aquatic enchytraeid Propappus volki (Oligochaeta) in an English chalkstream. Holarctic Ecology 5: 67-75.

Botea, F. R., 1963. Contributii la studiul răspîndirii olgochetelor limicole din R.P.R. (Valea Motrului) IV: 401-409.

Bou, C., 1977. Conséquences écologiques de l'extraction des alluvions récentes dans le cours moyen du Tarn. Bulletin d'Ecologie 8: 435-444.

Bou, C. \& R. Rouch, 1967. Un nouveau champ de recherches sur la faune aquatique souterraine. Comptes Rendus de l'Académie des Sciences, Paris 265: 369-370.

Boulton, A.J., 2000. River ecosystem health down under: assessing ecological conditions in riverine groundwater zones in Australia. Ecosystem Health 6: 108-118.

Boulton, A. J., W. F. Humphreys \& S. M. Eberhard, 2003. Imperilled subsurface waters in Australia: Biodiversity, threatening processes and conservation. Aquatic Ecosystem Health and Management 6: 41-54 
Bretschko, G., 1991. Bed sediments, groundwater and stream limnology. Verhandlungen Internationale Vereiningung für Theorische und Angewandte Limnologie 24: 1957-1960.

Brunke, M. \& T. Gonser, 1997. The ecological significance of exchange processes between rivers and groundwater. Freshwater Biology 37: 1-33.

Camus, J. C. \& M. Lafont, 1994. Etude de la vulnérabilité à la pollution du champ captant de Crépieux-Charmy (69). Utilisation des oligochètes et des microcrustacés. Cemagref: 48 pp.

Claret, C., P. Marmonier, M. J. Dole-Olivier, M. Creuzé des Châtelliers, A. J. Boulton \& E. Castella, 1999. A functional classification of interstitial invertebrates: supplementing measures of biodiversity using species traits and habitat affinities. Archiv für Hydrobiologie 145: 385-403.

Danielopol, D. L., 1984. Ecological investigations on the alluvial sediments of the Danube in the Vienna area - a phreatobiological project. Verhandlungen Internationale Vereiningung für Theorische und Angewandte Limnologie 22: 1755-1761.

Danielopol, D. L., 1989. Groundwater fauna associated with riverine aquifers. Journal of the North American Benthological Society 8: 18-35.

Datry, T., F. Hervant, F. Malard, L. Vitry \& J. Gibert, 2003. Dynamics and adaptive responses of invertebrates to suboxia in contaminated sediments of a stormwater infiltration basin. Archiv für Hydrobiologie 156: 339-359.

Dole, M. J., 1983. Le domaine aquatique souterrain de la plaine alluviale du Rhône à l'est de Lyon. I: diversité hydrologique and biocénotique de trois stations représentatives de la dynamique fluviale. Vie and Milieu 33: 219-229.

Dumnicka, E., 1986. Naididae (Oligochaeta) from subterranean waters of West Indian islands. Distribution, taxonomic remarks and description of a new species. Bijdragen tot de Dierkunde 56: 267-281.

Durbec, A., M. Lafont \& J. C. Camus, 1992. Etude de la vulnérabilité à la pollution du champ captant de Chasse-sur-Rhône (38). Burgéap-Cemagref: 16 pp.

Fellows, C. S., H. M. Valett \& C. N. Dahm, 2001. Whole-stream metabolism in two montane streams: Contribution of the hyporheic zone. Limnology and Oceanography 46: 523-531. 
Ferrarese, U. \& B. Sambugar, 1976. Ricerche sulla fauna interstiziale iporreica dell'Adige in relazione allo stato di inquinamento del Fiume. Rivista di Idrobiologia. 15: 47-127.

Gaschignard, O., 1984. Impact d'une crue sur les invertébrés benthiques d'un bras mort du Rhône. Verhandlungen Internationale Vereiningung für Theorische und Angewandte Limnologie 22: 19972001.

Gibert, J., 2000. Basic attributes of groundwater ecosystems. In Griebler, C., D. L. Danielopol, J. Gibert, H. P. Nachtnebel \& J. Notenboom (eds), Groundwater Ecology. European Communities: $39-52$.

Giere, O., 1993. Meiobenthology. The microscopic fauna in aquatic sediments. Springer-Verlag Berlin Heidelberg: 328 pp.

Griebler, C., D. L. Danielopol, J. Gibert, H. P. Nachtnebel \& J. Notenboom, 2001. Groundwater Ecology, European Communities.

Gibert, J., M. J. Dole-Olivier, P. Marmonnier \& P. Vervier, 1990. Surface water/groundwater ecotones. In Naiman R. J. \& H. Décamps (eds), Ecology and Management of Aquatic-Terrestrial Ecotones. UNESCO and Parthenon Publishing Group, Paris 4: 199-225.

Hancock, P. J., 2002. Human impacts on the stream-groundwater exchange zone. Environmental Management 29: 763-781.

Holmes, R. M., 2000. The importance of ground water to stream ecosystem function. In Jones, J. B. \& P. J. Mulholland (eds), Streams and Ground Waters. Academic Press, San Diego: 137-148.

Hynes, H. B. N., 1983. Groundwater and stream ecology. Hydrobiologia 100: 93-99.

Jones, J. B. \& P. J. Mulholland, 2000. Streams and Ground Waters. Academic Press, San Diego.

Juget, J., 1980. Aquatic oligochaeta of the Rhône-Alpes area: current research priorities. In Brinkhurst R. O. \& D. G. Cook (eds), Aquatic Oligochaete Biology. Plenum Press, New York and London: $241-251$

Juget, J., 1984. Oligochaeta of the epigean and underground fauna of the alluvial plain of the French upper Rhône (biotypological try). Hydrobiologia 115: 175-182. 
Juget, J., 1987. Contribution to the study of Rhyacodrilinae (Tubificidae, Oligochaeta), with the description of two new stygobiont species from the alluvial plain of the French Upper Rhône, Rhyacodrilus amphigenus, sp. n. and Rhizodriloides phreaticola, g. n., sp. n. Hydrobiologia 155: $107-118$

Juget, J. \& E. Dumnicka, 1986. Oligochaeta (incl. Aphanoneura) des eaux souterraines continentales. In Botosaneanu L. (ed.), Stygofauna mundi. E. J. Brill; Leiden: 234-244.

Juget, J. \& M. Lafont, 1994. Theoretical habitat templets, species traits, and species richness: aquatic Oligochaetes in the Upper Rhône River and its floodplain. Freshwater Biology 31: 327-340.

Ladle, M. 1971. Studies on the biology of oligochaetes from the phreatic water of an exposed gravel bed. International Journal of Speleology 3: 311-316 +4 Plates (100-103).

Lafont, M., 1989. Contribution à la gestion des eaux continentales: utilisation des oligochètes comme descripteurs de l'état biologique et du degré de pollution des eaux et des sédiments. Thèse de Doctorat ès Sciences, Université Lyon I: 403 pp.

Lafont, M., 2001. A conceptual approach to the biomonitoring of freshwater: the Ecological Ambience System. Journal of Limnology 60 Suppl. 1: 17-24.

Lafont, M. \& A. Durbec, 1990. Essai de description biologique des interactions entre eau de surface et eau souterraine: application à l'évaluation de la vulnérabilité d'un aquifère à la pollution d'un fleuve. Annales de Limnologie 26: 119-129.

Lafont, M. \& F. Malard, 2001. Oligochaete communities in the hyporheic zone of a glacial river, the Roseg River, Switzerland. Hydrobiologia 463: 75-81.

Lafont, M., A. Durbec \& C. Ille, 1992. Oligochaete worms as biological describers of the interactions between surface and groundwater: a first synthesis. Regulated Rivers, Research and Management 7: $65-73$.

Lafont, M., Camus J. C \& Rosso A. 1996. Superficial and hyporheic oligochaete communities as indicators of pollution and water exchange in the River Moselle, France. Hydrobiologia 334: 147155. 
Lafont, M., J. C. Camus, A. Fournier \& E. Sourp, 2001. A practical concept for the ecological assessment of aquatic ecosystems: application on the river Dore in France. Aquatic Ecology 35: 195-205.

Lafont, M., A. Vivier, S. Nogueira, P. Namour \& P. Breil. Surface and hyporheic Oligochaete assemblages in a French suburban stream. Accepted for publication in Hydrobiologia.

Malard, F., 2001. Groundwater contamination and ecological monitoring in a mediterranenan karst ecosystem in southern France. In Griebler C., D. L. Danielopol, J. Gibert, H. P. Nachtnebel \& J. Notenboom (eds), Groundwater Ecology. European Communities: 183-194.

Malard, F., K. Tockner \& J. V. Ward, 1999. Shifting dominance of subcatchment water sources and flow paths in a glacial floodplain (Val Roseg, Switzerland). Arctic, Antarctic, and Alpine Research 3: 135-150.

Malard, F., M. Lafont, P. Burgherr \& J. V. Ward, 2001. A comparison of longitudinal patterns in hyporheic and benthic oligochaete assemblages in a glacial river. Arctic, Antarctic, and Alpine Research 33: 457-466.

Malard, F., K. Tockner, M. J. Dole-Olivier \& J. V. Ward, 2002. A landscape perspective of surfacesubsurface hydrological exchanges in river corridors. Freshwater Biology 47: 621-640.

Malard, F., D. Galassi, M. Lafont, S. Doledec \& J. V. Ward, 2003. Longitudinal pattern of invertebrates in the hyporheic zone of a glacial river. Freshwater Biology 48: 1-17.

McElravy, E. P. \& V. Resch, 1991. Distribution and seasonal occurrence of the hyporheic fauna in a northern California stream. Hydrobiologia 220: 233-246.

Mermillod-Blondin, F., M. Creuzé des Châtelliers \& M. Gérino, 2003. Effects of the interaction between tubificid worms on the functioning of hyporheic sediments: an experimental study in sediment columns. Archiv für Hydrobiologie 156: 203-223.

Nalepa, T. F. \& A. Robertson, 1981. Screen mesh size affects estimates of macro- and meio-benthos abundance and biomass in the Great Lakes. Canadian Journal of Fisheries and Aquatic Sciences 38: 1027-1034.

Rouch, R. \& D. L. Danielopol, 1987. L'origine de la faune aquatique souterraine, entre le paradigme du refuge et le modèle de la colonisation active. Stygologia 3: 345-372. 
Sambugar, B., N. Giani \& E. Martinez-Ansemil, 1999. Groundwater oligochaetes from SouthernEurope. Tubificidae with marine phyletic affinities: new data with description of a new species, review and consideration on their origin. Mémoires de Biospéologie XXVI: 107-116.

Schwank, Von P., 1982a. Turbellarien, Oligochaeten und Archianneliden des Breitenbachs und anderer oberhessischer Mittelgebirgsbäche. III. Die Taxozönosen der Turbellarien und Oligochaeten in Fließgewässern - eine synökologische Gliederung. Archiv für Hydrobiologie/Supplementum 62: 191-253.

Schwank, Von P., 1982b. Turbellarien, Oligochaeten und Archianneliden des Breitenbachs und anderer oberhessischer Mittelgebirgsbäche. IV. Allgemeine Grundlagen der Verbreitung von Turbellarien und Oligochaeten in Fließgewässern. Archiv für Hydrobiologie/Supplementum 62: 254-290.

Solbe, J. F., 1975. Annelida. In Curds C. R. \& H. A. Hawkes (eds), Ecological aspect of used water treatment,Academic Press, London: 305-335.

Solbe, J. F., P. G. Ripley \& T. G. Tomlinson, 1974. The effects of temperature on the performance of experimental percolating filters with and without mixed macro-invertebrate populations. Water Research, 8: 557-573.

Stanley, E. H. \& J. B. Jones, 2000. Surface-subsurface interactions: past, present, and future. In: Jones, J. B. \& P. J. Mulholland (eds), Streams and Ground Waters. Academic Press, San Diego 405-417. Strayer, D. \& E. Bannon-O'Donnell, 1988. Aquatic Microannelids (Oligochaeta and Aphanoneura) of undergroundwaters of Southeastern New-York. The American Midland Naturalist 119: 327-335.

Triska, F. J., J. H. Duff \& R. J. Avanzino, 1990. Influence of exchange flow between the channel and hyporheic zone on $\mathrm{NO}_{3}{ }^{-}$production in a small mountain stream. Canadian Journal of Fisheries and Aquatic Sciences 11: 2099-2111.

Valett, H. M., C. C.Hakenkamp \& A. J. Boulton, 1993. Perspectives on the hyporheic zone: integrating hydrology and biology. Introduction. Journal of the North American Benthological Society 12: 40-43. 
Vervier, P., J. Gibert, P. Marmonnier \& M. J. Dole-Olivier, 1992. A perspective on the permeability of the surface freshwater-groundwater interface. Journal of the North American Benthological Society 11: 93-102.

Ward, J. V., 1989. The four-dimensional nature of lotic ecosystems. Journal of the North American Benthological Society 8: 2-8.

Ward, J. V. \& M. A. Palmer, 1994. Distribution patterns of interstitial freshwater meiofauna over a range of spatial scales, with emphasis on alluvial river-aquifer systems. Hydrobiologia 287: 147156.

Weigelhoffer, G. \& J. Waringer, 2003. Vertical distribution of benthic macroinvertebrates in riffles versus deep runs with differing contents of fine sediments (Weidlingbach, Austria). International Revue of Hydrobiology 88: 304-313.

White, D. S., 1993. Perspectives on defining and delineating hyporheic zones. Journal of the North American Benthological Society: 61-69.

Williams, N. V. \& H. M. Taylor, 1968. The effect of Psychoda alternata (Say.) (Diptera) and Lumbricillus rivalis (Levinsen) (Enchytraeidae) on the efficiency of sewage treatment in percolating filters. Water Research, 2: 139-150. 
Table 1. Structure of oligochaete assemblages at four transects at the Grand Gravier site (River Rhône); (1): pollution-tolerant Tubificidae, excluding Spirosperma velutinus and Psammoryctides barbatus; AED: Active Exchange Describers (Pristina and Pristinella spp., Cernosvitoviella sp., Stylodrilus sp., S. velutinus, Rhyacodrilus sp.); from Lafont \& Durbec (1990); Lafont et al. (1992).

\begin{tabular}{|c|c|c|c|c|c|c|c|}
\hline \multirow[b]{2}{*}{ Transects } & \multicolumn{2}{|c|}{ Station 1} & \multicolumn{2}{|c|}{ Station 2} & \multicolumn{3}{|c|}{ Deep zone } \\
\hline & $\mathrm{T} 1$ & $\mathrm{~T} 2$ & $\mathrm{~T} 3$ & $\mathrm{~T} 4$ & $-1.5 \mathrm{~m}$ & $-4 m$ & $-8 m$ \\
\hline$\%$ Tubificidae (1) & 60 & 72 & 26.5 & 44.5 & 8 & 42.5 & 42 \\
\hline$\%$ AED & 2.5 & 4 & 21.5 & 48 & 2 & 11 & 1.5 \\
\hline \multicolumn{8}{|l|}{ Filtration flow velocities } \\
\hline (max flow velocity., $\mathrm{m}$ day $^{-1}$ ) & \multicolumn{2}{|c|}{23} & \multicolumn{2}{|c|}{33} & & & \\
\hline (mean flow velocity., $\mathrm{m}$ day $^{-1}$ ) & & & & & 2.7 & 6.3 & 2.3 \\
\hline
\end{tabular}


Table 2. List of Active Exchange Describers (AED); from Juget \& Lafont (1994); Lafont (unpublished data); Lafont et al. (1992 and accepted); Sambugar et al. (1999); **: mentioned in the surface and hyporheic sediments of the glacial river Roseg (Malard et al., 2001).

\section{Hydrologically validated AED}

Spirosperma velutinus,

all the Rhyacodrilinae and Phallodrilinae species, including Rhyacodrilus coccineus all the species belonging to the Genera Pristina and Pristinella, Chaetogaster parvus, Stylodrilus spp., including S. heringianus**, Rhynchelmis spp., Trichodrilus spp., Bichaeta sanguinea (all the Lumbriculidae, except Lumbriculus variegatus), Cernosvitoviella spp., including C. atrata** and C. carpatica**, Achaeta spp., Marionina argentea** Haplotaxis gordioides**; Dorydrilus michaelseni**; Propappus volki**

\section{Suspected AED (need for validation)}

Bothrioneurum spp., Aulodrilus pigueti, Quistadrilus multisetosus, Haber spp., Lumbricillus fennicus, Tubifex kessleri, Mesenchytraeus armatus, Nais communis ** (eyeless populations) 


\section{Figure captions}

\section{Figure 1:}

River Moselle at Station 1 (slight pollution, no water-pumping in ground water); annual evolution of the river discharges $\left(\mathrm{m}^{3} \cdot \mathrm{s}^{-1}\right)$ and groups of oligochaete species $(\mathrm{Gr} 1, \mathrm{Gr} 3)$ that predominated both in surface sediments $(\mathrm{S})$ and the hyporheic layer $(\mathrm{H})$; the vertical arrows correspond to the sampling dates of oligochaete assemblages .

\section{Figure 2:}

River Moselle at Station 4 (strong pollution, water-pumping in ground water); annual evolution of the river discharges $\left(\mathrm{m}^{3} \cdot \mathrm{s}^{-1}\right)$ and group of oligochaete species $(\mathrm{Gr} 2)$ that predominated both in surface sediments (S) and the hyporheic layer $(\mathrm{H})$; the vertical arrows correspond to the sampling dates of oligochaete assemblages .

\section{Figure 3}

Plot of the river Rhône at Chasse-sur-Rhône site (October 1992); P1 to P5: sampling stations; percentages of pollution-tolerant species of Tubificidae in the surface (\% TUB.S.) and hyporheic (\% TUB.H.) layers.

\section{Figure 4}

The Crépieux-Charmy site ; the ways of the water exchanges between surface and subsurface were mapped in July 1994 by the examination of crustacean (C) and oligochaete (O) assemblages. 
Lafont M. \& A. Vivier - Figure 1

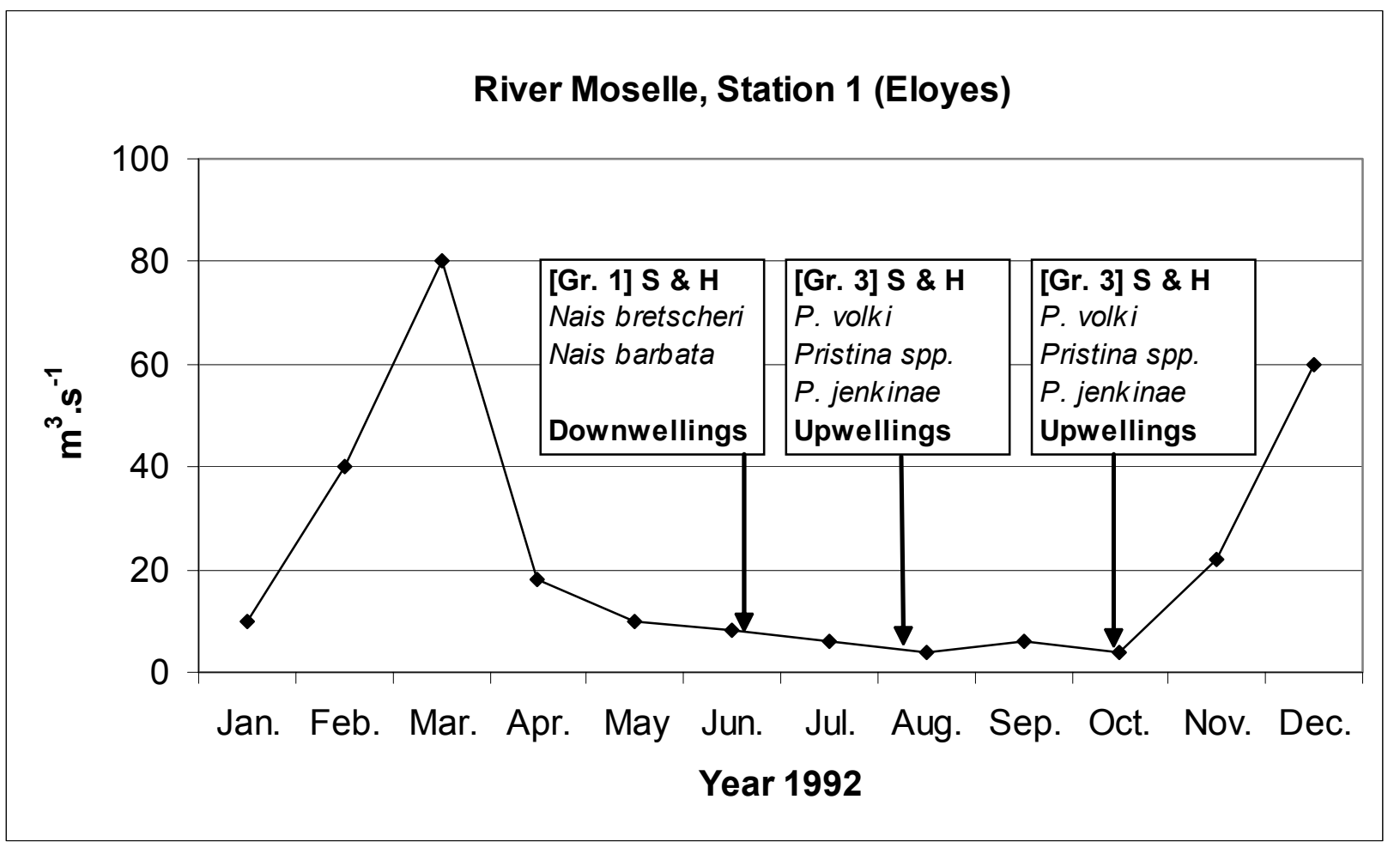


Lafont M. \& A. Vivier., Figure 2

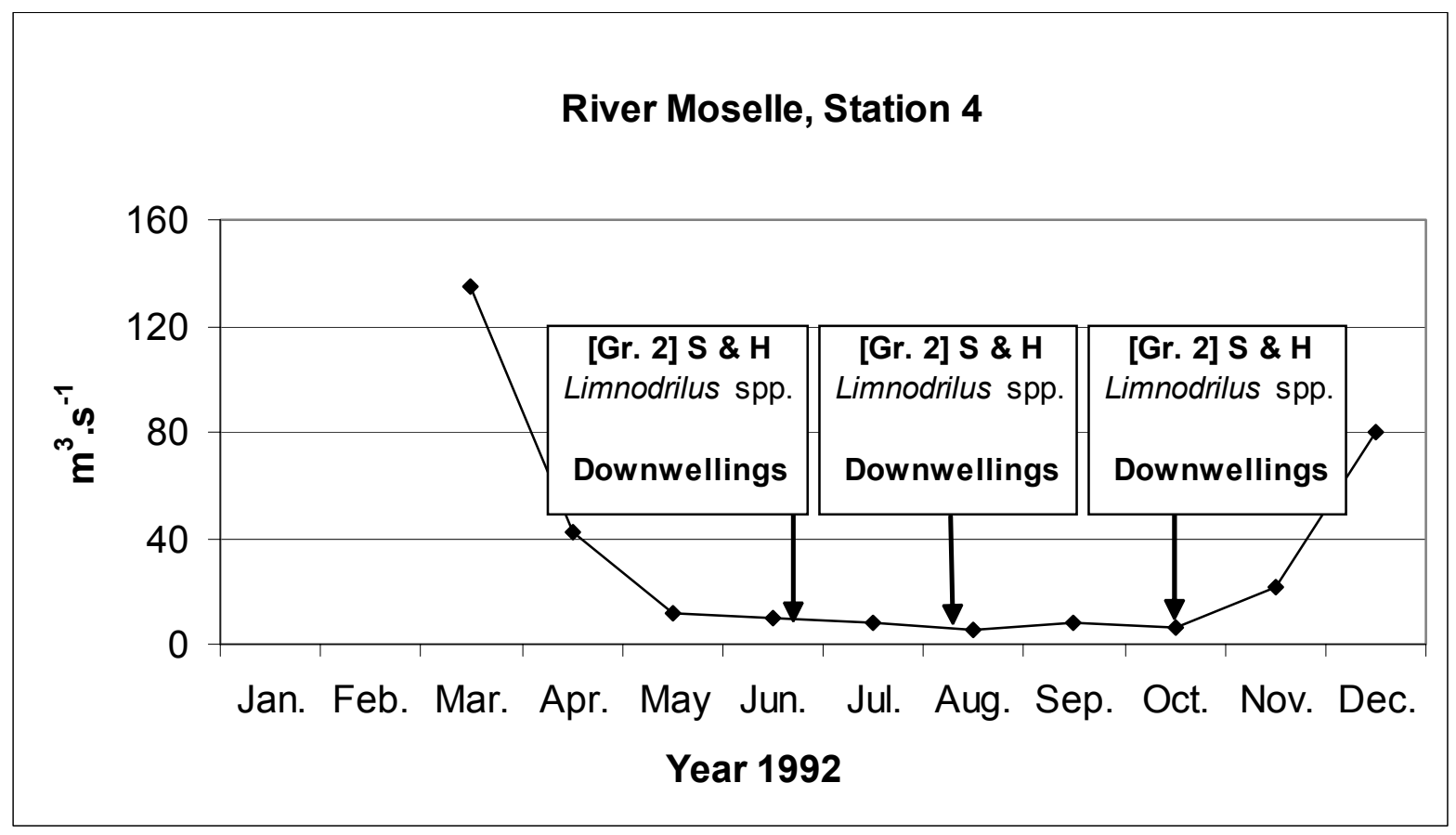


Lafont M. \& A. Vivier., Figure 3

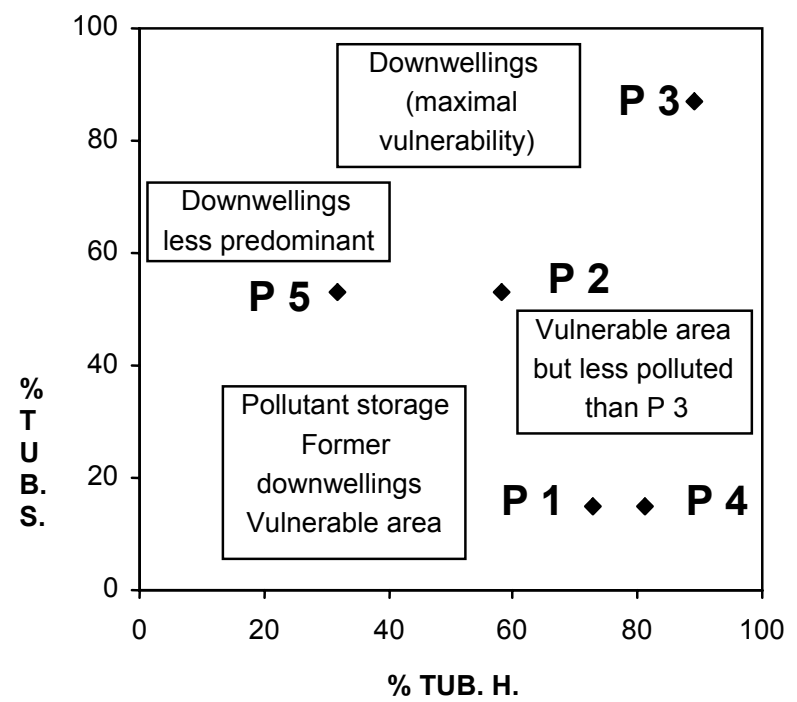


Lafont M. \& A. Vivier., Figure 4

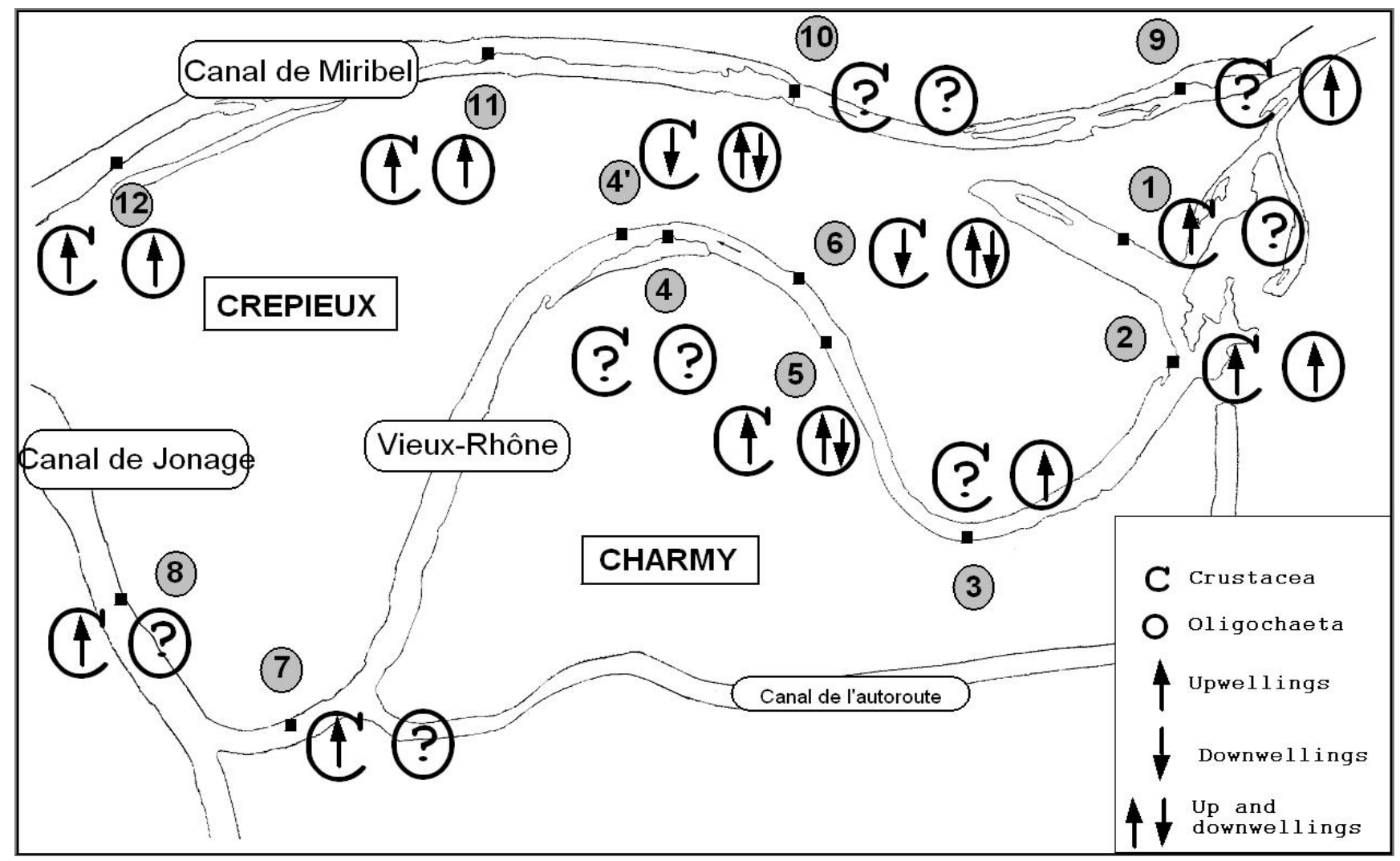

